\title{
Climatic controls and climate proxy potential of Lewis Glacier, Mt. Kenya
}

\author{
R. Prinz ${ }^{1,2}$, L. I. Nicholson ${ }^{2}$, T. Mölg ${ }^{3}$, W. Gurgiser ${ }^{2}$, and G. Kaser ${ }^{2}$ \\ ${ }^{1}$ Department of Geography and Regional Science, University of Graz, Heinrichstraße 36, 8010 Graz, Austria \\ ${ }^{2}$ Institute of Atmospheric and Cryospheric Sciences, until May 2015 known as the Institute of Meteorology and Geophysics, \\ University of Innsbruck, Innrain 52, 6020 Innsbruck, Austria \\ ${ }^{3}$ Institute of Geography, Friedrich-Alexander University Erlangen-Nürnberg (FAU), Wetterkreuz 15, \\ 91058 Erlangen, Germany
}

Correspondence to: R. Prinz (rainer.prinz@uni-graz.at)

Received: 29 May 2015 - Published in The Cryosphere Discuss.: 28 July 2015

Revised: 26 November 2015 - Accepted: 23 December 2015 - Published: 18 January 2016

\begin{abstract}
The Lewis Glacier on Mt. Kenya is one of the best studied tropical glaciers and has experienced considerable retreat since a maximum extent in the late 19th century (L19). From distributed mass and energy balance modelling, this study evaluates the current sensitivity of the surface mass and energy balance to climatic drivers, explores climate conditions under which the L19 maximum extent might have been sustained, and discusses the potential for using the glacier retreat to quantify climate change. Multi-year meteorological measurements at $4828 \mathrm{~m}$ provide data for input, optimization, and evaluation of a spatially distributed glacier mass balance model to quantify the exchanges of energy and mass at the glacier-atmosphere interface. Currently the glacier loses mass due to the imbalance between insufficient accumulation and enhanced melt, because radiative energy gains cannot be compensated by turbulent energy sinks. Exchanging model input data with synthetic climate scenarios, which were sampled from the meteorological measurements and account for coupled climatic variable perturbations, reveals that the current mass balance is most sensitive to changes in atmospheric moisture (via its impact on solid precipitation, cloudiness, and surface albedo). Positive mass balances result from scenarios with an increase of annual (seasonal) accumulation of $30 \%(100 \%)$, compared to values observed today, without significant changes in air temperature required. Scenarios with lower air temperatures are drier and associated with lower accumulation and increased net radiation due to reduced cloudiness and albedo. If the scenarios currently producing positive mass balances are ap-
\end{abstract}

plied to the L19 extent, negative mass balances are the result, meaning that the conditions required to sustain the glacier in its L19 extent are not reflected in today's meteorological observations using model parameters optimized for the present-day glacier. Alternatively, a balanced mass budget for the L19 extent can be achieved by changing both climate and optimized gradients (used to extrapolate the meteorological measurements over the glacier) in a manner that implies a distinctly different coupling between the glacier's local surface-air layer and its surrounding boundary layer. This result underlines the difficulty of deriving palaeoclimates for larger glacier extents on the basis of modern measurements of small glaciers.

\section{Introduction}

Glaciological observations in east Africa over the last century have shown a pronounced decrease in glacier length, area, and mass (Cullen et al., 2013; Hastenrath, 1984, 2005b, 2008; Mölg et al., 2013; Prinz et al., 2011, 2012). Immediate changes in glacier mass are governed by concurrent weather and, consequently, by climate through energy and mass exchanges between the glacier surface and the atmosphere. Integrated over time, and filtered by glacier dynamics, these exchanges result in changes in glacier extent. Thus, an accurate understanding of the glacier-climate interaction can be used to reveal the main atmospheric drivers of observed glacier extent changes. 
The identification of climate signals from glaciers in east Africa is of particular interest because they exist in elevations between approximately 5 and $6 \mathrm{~km}$ a.s.l. (above sea level) and therefore capture climate signals from the midtroposphere (Mölg et al., 2009b), where our knowledge of climate change is scarce and controversial (e.g. Hartmann et al., 2013; Karl et al., 2006; Pepin and Lundquist, 2008). The air temperature regime of the tropical east African climate - in particular at high elevations - is dominated by a pronounced diurnal cycle, driven by high incoming global radiation during daytime and strong long-wave energy loss during the night (Hastenrath, 1983), resulting in diurnal air temperature variations being larger than seasonal air temperature variations. In contrast to the thermal seasonality in the mid-latitudes, the annual cycle in the tropics is dominated by a hygric seasonality, expressed in the "long rains" (March to May) and the "short rains" (October to December), driven by the passage of the intertropical convergence zone (e.g. Mutai and Ward, 2000) and modulated by sea surface temperatures in the Indian and Pacific oceans (e.g. Yang et al., 2014a). During recent decades, precipitation variability in east Africa has shown a drying trend especially in the long rains (Schmocker et al., 2015; Yang et al., 2014b) due to changing sea surface temperature patterns, for which reasons are not completely understood yet and might be caused by both natural variability (Yang et al., 2014b) and/or anthropogenic origin (Williams and Funk, 2011). As a consequence of the tropical hygric seasonality and year-round warm air temperatures, tropical glaciers can experience ablation and accumulation at any time during the year, although accumulation tends to be concentrated in the regional wet seasons. This is in contrast to mid- and high-latitude glaciers where separate accumulation and ablation seasons are pronounced.

While some initially speculated that glacier recession on Kilimanjaro is caused by rising local air temperature, subsequent physical, process-resolving studies - based on and evaluated with in situ observations - revealed that glaciers on Kilimanjaro are most sensitive to changes in atmospheric moisture and precipitation (Mölg and Hardy, 2004; Mölg et al., 2008, 2009b) due to their location far above the mean annual freezing level. Although there are additional controls on the peculiar plateau ice fields (Kaser et al., 2010; Winkler et al., 2010), the ongoing retreat of slope glaciers on Kilimanjaro since the late 19th century has therefore been driven by the development of a drier regional atmosphere during the 20th and 21st century (Mölg et al., 2009b). This drying is related to changing ocean conditions which shift the Walker cell circulation over the Indian Ocean, thereby suppressing the convection along the east African continental margin (Chou et al., 2009; Lintner and Neelin, 2007; Mölg et al., 2006; Nicholson, 1996; Tierney et al., 2013; Webster et al., 1999), inhibiting the deep convection required to bring cloud cover and precipitation to the glaciated mountain summit (Mölg et al., 2009a). Both precipitation amount and frequency are reduced, and this combination reduces both the mass additions to the glaciers and the impact of frequent snowfall on surface albedo (Mölg et al., 2009b). The glaciological evidence for a drier atmosphere since the late 19th century is in accordance with alternative proxy climate records that indicate that the decades immediately preceding 1880 were humid, and characterized by high lake levels and relatively abundant precipitation (e.g. Konecky et al., 2014; Nicholson and Yin, 2001; Verschuren et al., 2000).

In contrast to the glaciers on Kilimanjaro, glaciers on Mt. Kenya and on Rwenzori exist close to the elevation of the mean regional freezing level, so they can be expected to show more sensitivity to air temperatures than the glaciers of Kilimanjaro. The Lewis Glacier (LG) is the largest glacier on Mt. Kenya and has been retreating since the late 19th century. Since 1934 the negative mass balance rate has been in line with global estimates of glacier mass balance but since the early 1970 s it has been significantly more negative than the global mean (Prinz et al., 2011). Past studies on Mt. Kenya used careful assumptions, simple parameterizations, and limited meteorological data to attribute the observed retreat of LG to combined changes in radiation geometry, air temperature, precipitation, albedo, and cloudiness (Hastenrath and Kruss, 1992; Hastenrath, 2010; Kruss and Hastenrath, 1987, 1990; Kruss, 1983). Although pioneering for their time, 2.5 years of in situ meteorological data are now available to allow a more rigorous assessment of the climate sensitivity of the glaciers here and explore if, due to their lower elevation, they offer a different climatic proxy than that offered by the glaciers of Kilimanjaro.

Nicholson et al. (2013) investigated the recent micrometeorological conditions and energy fluxes on LG at the point scale, in the context of other tropical glaciers. Conditions at the summit of Mt. Kenya were found to be much warmer and more humid than on Kilimanjaro, allowing convective clouds to converge over the summit of Mt. Kenya much more frequently than over the summit of Kilimanjaro, even though both summits are influenced by the same air masses. The point modelling undertaken by Nicholson et al. (2013) suggests that, unlike on Kilimanjaro, the glacier mass balance variability is not dominated by a single variable or season. Building on that work, this paper aims to (i) extend the point surface energy and mass balance from Nicholson et al. (2013) to glacier wide-values for LG, (ii) evaluate the climate sensitivity of the glacier-wide surface mass and energy balance, (iii) explore climate conditions under which the late 19th century maximum extent of LG might have been sustained and (iv) discuss the potential for using shrinkage of LG to quantify climate change for a time period not covered by instrumental records. 


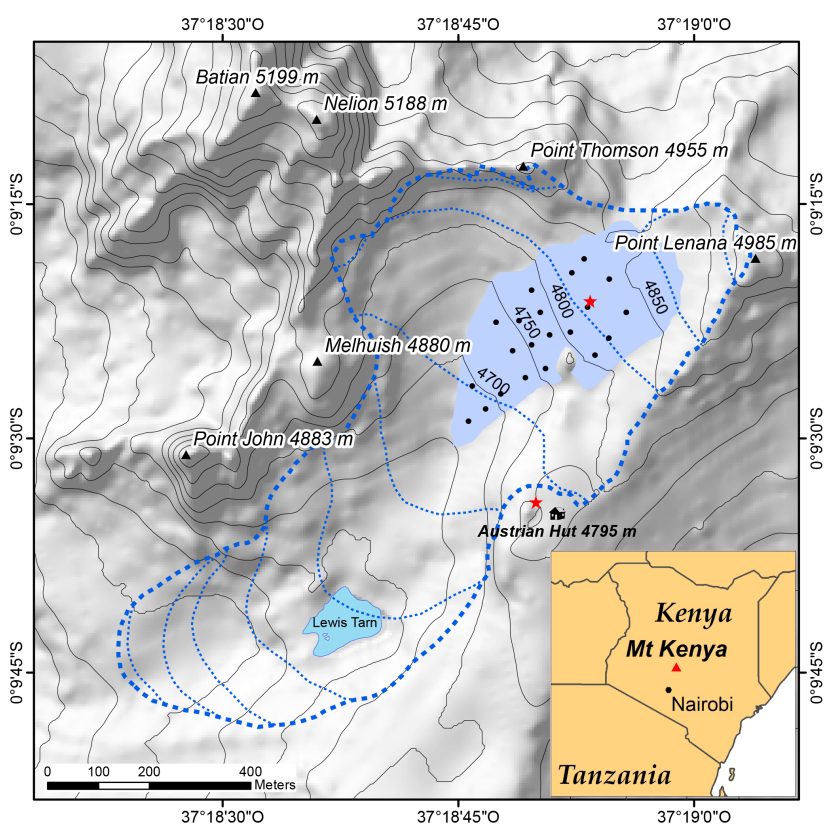

Figure 1. Overview map of LG, Mt. Kenya, for $2010\left(0.1 \mathrm{~km}^{2}\right)$ and the late 19 th century (L19, $0.6 \mathrm{~km}^{2}$, dashed). Red stars denote AWS locations, black dots the ablation stakes. L19 outline from Patzelt et al. (1984) with reconstructed contour lines. Off-glacier contours were taken from Schneider (1964) and updated for the LG basin in 2010 (Prinz et al., 2012). The mean wind direction for the depicted weather stations is south-east, invariant over the course of the year. The mean daily cycle of wind direction is east during the night and early morning and south from late morning to late afternoon.

\section{Data and methods}

\subsection{Study site and in situ meteorological and mass balance observations}

Lewis Glacier $\left(0.1 \mathrm{~km}^{2}\right.$ in 2010$)$ lies $\sim 370 \mathrm{~m}$ below the summit of Mt. Kenya in a south-westerly exposed, quasicirque location between the true summit and a secondary peak (Fig. 1). Several authors have surveyed LG since 1934 (Prinz et al. (2011) and references therein) and reconstructed the late 19th century maximum extent (L19) from moraines and sketches (Patzelt et al., 1984). The most recent mapping was performed in 2010 (Prinz et al., 2011, 2012) and is used as a topographic reference in this paper.

An automatic weather station (AWS) was installed on the glacier surface at an elevation of $4828 \mathrm{~m}$ which is $\sim 30 \mathrm{~m}$ below the upper limit of the glacier. Meteorological data are available from 26 September 2009 to 22 February 2012. However, there are two gaps in the records: from 25 January to 2 March 2010 (for surface height change and wind direction records only, because the mast was rotating), and from 20 July to 29 September 2010 (because the AWS mast broke). Thus, 773 days of complete data collected from the glacier surface, in three separate periods, are available
Table 1. Periods of available meteorological input for crossvalidation.

\begin{tabular}{llc}
\hline Period & From/to & $\begin{array}{c}\text { Number } \\
\text { of days }\end{array}$ \\
\hline 1 & 26 September 2009-24 January 2010 & 121 \\
2 & 2 March 2010-19 July 2010 & 140 \\
3 & 29 September 2010-1 March 2011 & 154 \\
4 & 2 March 2011-14 September 2011 & 197 \\
5 & 15 September 2011-22 February 2012 & 161 \\
\hline
\end{tabular}

for analysis. All instruments on the AWS (see Table 1 in Nicholson et al., 2013) are naturally ventilated, measured every $1 \mathrm{~min}$, and half-hourly averages are stored on a Campbell Scientific CR3000 data logger. Nicholson et al. (2013) demonstrated that the shielded, unventilated air temperatures and relative humidity measured at this site do not appear to suffer from distortions from solar heating of the sensors. On 24 February 2012, the AWS was moved off the ice and mounted on solid rock ("Radio Ridge") next to Austrian Hut at an elevation of $4809 \mathrm{~m}$. The system set-up was upgraded with a data transmission via satellite, but the number of sensors was reduced: sensors to measure air pressure and surface height were omitted, the four-component radiometer was replaced by a single pyranometer (EKO MS-602) and the data logger was changed to a Campbell Scientific CR1000. This provides 872 days (25 February 2012 to 30 September 2014; data gap 22 December 2012 to 9 March 2013) of complementary off-glacier AWS data from Radio Ridge. All AWS data used in this study are quality controlled as described by Nicholson et al. (2013).

All-phase precipitation measurements are not available at the frequency required for the modelling, so in this study only solid precipitation determined from surface height changes recorded by a sonic ranger, and limited field measurements of snow density, are considered. Fresh snow density in the field was found to be in the range of 330$430 \mathrm{~kg} \mathrm{~m}^{-3}$, presumably indicating that snowfall here is typically very wet and/or contains a high proportion of graupel. Although very high compared to higher-latitude snow measurements, the fresh snow density of $315 \mathrm{~kg} \mathrm{~m}^{-3}$ used here was based on these measurements and model optimization, and is in line with other measurements at tropical glaciers (Sicart et al., 2002).

The mass balance of LG was measured from 1979 to 1996 (Hastenrath, 2005a) and measurements were restarted in September 2009. Since then annual or biannual observations were performed at 26 ablation stakes distributed evenly across LG until February 2014. Point and glacier-wide specific mass balances are reported to the World Glacier Monitoring Service and are accessible through their online data browser (http://www.wgms.ch/). Because of the aforementioned data gaps in the AWS record, a concurrent time series of AWS measurements and mass balance observations over a 
complete mass balance year only exists for the 2011/12 mass balance year, spanning 358 days between 2 March 2011 and 22 February 2012.

\subsection{Mass and energy balance modelling}

A detailed process-based mass balance model (MBM) is able to resolve the complexity of the transient mass and energy fluxes that force the surface mass balance of a glacier. The model used in this study originates from an energy balance model (Mölg and Hardy, 2004), that was developed into a mass balance model suitable for single point or glacier-wide applications (Mölg et al., 2008, 2009b). The model structure used in this study is explained in detail by Mölg et al. (2012) with the latest model version (2.4) used by Mölg (2015). The model calculates the surface and near-subsurface mass and energy fluxes and has been successfully applied to address various questions in a range of climatic conditions (Collier et al., 2013; Conway and Cullen, 2015; Cullen et al., 2007, 2014; Gurgiser et al., 2013a, b; MacDonell et al., 2013; Mölg et al., 2014; Nicholson et al., 2013). The model computes the mass balance as the sum of solid precipitation, surface deposition, internal accumulation (refreezing of liquid water in snow), change in englacial liquid water storage, subsurface and surface melt, and sublimation. This approach is based on the surface energy balance of a glacier in the following form:

$$
\begin{aligned}
\mathrm{SWI}(1-\alpha) & +\mathrm{LWI}+\mathrm{LWO}+Q_{\mathrm{S}}+Q_{\mathrm{L}}+Q_{\mathrm{PRC}} \\
& +Q_{\mathrm{C}}+Q_{\mathrm{PS}}=F,
\end{aligned}
$$

where SWI is incoming short-wave radiation (global radiation corrected for aspect/slope), $\alpha$ is surface albedo, LWI and LWO are incoming and outgoing long-wave radiation fluxes, $Q_{S}$ and $Q_{L}$ are the turbulent fluxes of sensible and latent heat, respectively, $Q_{P R C}$ is the heat flux from precipitation, $Q_{C}$ the conductive heat flux in the subsurface, and $Q_{P S}$ the energy flux from short-wave radiation penetrating into the subsurface. The sum of these fluxes yields a residual flux $F$ which, if the glacier surface temperature (TS) reaches $273.15 \mathrm{~K}$, represents the latent energy for melting. If TS is below $273.15 \mathrm{~K}$, energy conservation is achieved by solving TS to balance the fluxes (Mölg et al., 2009b; van den Broeke et al., 2006). Input data for mass accumulation are provided by a surface height change record or as water equivalent, and SWI, $\alpha$, LWI, LWO, air temperature, atmospheric humidity, air pressure, and wind speed are required in order to solve the energy balance for the remaining mass fluxes. The model can be validated on the basis of measured surface height changes at the AWS and nearby reference stakes, and/or with TS measured directly or derived from measured LWO. In order to enable glacier-wide mass balance runs and sensitivity tests, some of these input variables must be replaced by parameterizations based on key atmospheric properties that can then be varied in the sensitivity study. Thus, SWI, $\alpha$, and LWI are parameterized and TS (LWO) is computed from the energy balance as noted above, to capture the feedback effects on the mass balance in case of a climate perturbation (Mölg et al., $2009 \mathrm{~b}$ ). The required MBM inputs are therefore reduced to air temperature and humidity, air pressure, a cloud cover factor, wind speed, and accumulation rate. Additionally, for the spatially distributed case, a digital elevation model is compulsory as lower boundary condition, from which the grid cell sky view and shading parameters are computed. Vertical gradients in precipitation and air temperature are essential parameters to distribute the meteorological data from the AWS to the whole glacier surface. For this study all meteorological input data are provided from the AWS record and aggregated to the model time step of $1 \mathrm{~h}$ for computational efficiency.

\subsection{Parameterization of radiative fluxes}

Cloudiness is a crucial factor governing the radiative fluxes but is difficult to obtain. Thus, it is derived from parameterizing global radiation, employing an approach from Budyko (1974), which was applied for equatorial east Africa in earlier studies (Hastenrath, 1984; Mölg et al., 2009c):

$G=\left(S_{c s}+D_{c s}\right)\left(1-k n_{\mathrm{eff}}\right)$,

where $G$ is the global radiation, separated into direct and diffuse clear sky components $\left(S_{\mathrm{cs}}\right.$ and $\left.D_{\mathrm{cs}}\right)$, and $n_{\text {eff }}$ is the effective cloud cover fraction $(0-1)$. The constant $k$ controls the global radiation under cloudy conditions. First, clear sky $G$ is modelled using concepts of Iqbal (1983) and Meyers and Dale (1983), and it is optimized against measured clear sky days (Mölg et al., 2009c), defined from the meteorological record at the AWS when $G$ was $>77 \%$ of top of the atmosphere radiation and mean daily long-wave net radiation was lower than its fifth percentile as a proxy for absent cloudiness (van den Broeke et al., 2006). From 773 days, only 17 clear sky days were found, all occurring in late December to late February. All-sky $G$ is modelled by optimizing the product $k n_{\text {eff }}$ over the total measurement period (773 days) and yielding a $k$ of 0.72 , meaning that under completely overcast conditions, $G$ is $28 \%$ of its potential clear sky value. Hastenrath (1984) previously used $k$ of 0.65 for Mt. Kenya, based on values from literature, and Mölg et al. (2009c) used an optimization based on 700 days of meteorological data to determine that $k$ is 0.65 for the clearer, drier conditions on the summit of Kilimanjaro (Nicholson et al., 2013). Hence, the higher $k$ calculated for Mt. Kenya is reasonable. Mean daily daytime values of modelled $G$ correlate highly with measured $G(r=0.99)$ with a root-mean-square error (RMSE) of $25.4 \mathrm{~W} \mathrm{~m}^{-2}$ (Fig. 2). Modelling $G$ outside the calibration period (872 days of AWS on Radio Ridge) yielded very similar statistics ( $r=0.99$ and RMSE of $\left.27.0 \mathrm{~W} \mathrm{~m}^{-2}\right)$, indicating that despite the limited number of clear sky days available for model optimization, the parameterization scheme is robust.

LWI is described by the Stefan-Boltzmann law and depends on the atmospheric emissivity $\left(\varepsilon_{\mathrm{A}}\right)$, the StefanBoltzmann constant $(\sigma)$, and the absolute temperature of the 

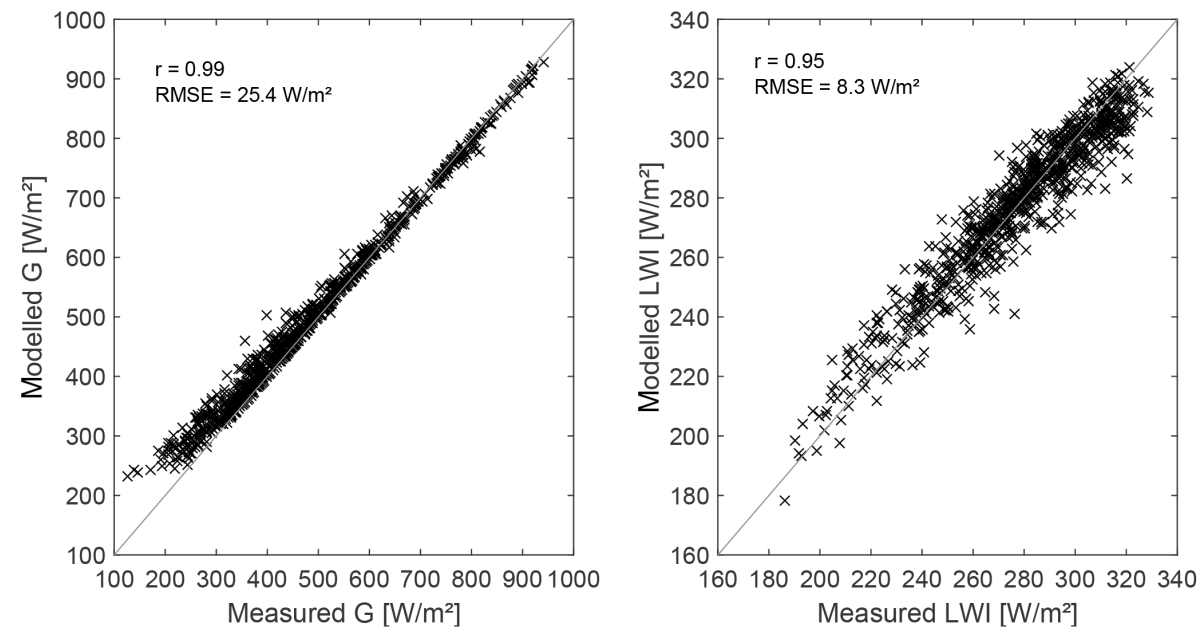

Figure 2. Parameterization performance of downward radiative fluxes for 772 days at the location of the AWS. Scatter plot of mean daily measured versus modelled $G$ (left panel) and LWI (right panel). Hourly values show similar correlation of $r=0.99(0.93)$ and $\mathrm{RSME}=26.4(33.8) \mathrm{W} \mathrm{m}^{-2}$ for $G(\mathrm{LWI})$, respectively.

air. The presence of clouds increases $\varepsilon_{\mathrm{A}}$ by a cloud factor $F_{\mathrm{cl}}(\geq 1)$, which is thus positively correlated with $n_{\mathrm{eff}}$ (Niemelä et al., 2001) and can be written as the ratio of all sky LWI/clear sky LWI (Mölg et al., 2009c; Sicart et al., 2006).

$\mathrm{LWI}=\varepsilon_{\mathrm{Acs}} \sigma T^{4} F_{\mathrm{cl}}$

For clear sky LWI, the clear sky atmospheric emissivity $\left(\varepsilon_{\text {Acs }}\right)$ was derived optimizing the constants $c_{1}$ (1.24) and $c_{2}$ (7.6) in an empiric relationship from Brutsaert (1975):

$\varepsilon_{\mathrm{Acs}}=c_{1}\left(\frac{e}{T}\right)^{\frac{1}{c_{2}}}$,

where $e$ is the atmospheric vapour pressure and $T$ the absolute air temperature. Finally, all sky LWI is modelled, finding an optimal function $F_{\mathrm{cl}}\left(n_{\text {eff }}\right)$. As $n_{\text {eff }}$ is just defined during daytime, clear sky conditions are assumed during the night, which is feasible in this tropical environment where cloudiness, humidity, and precipitation follow the pronounced daily cycle of convection. Mean daily values of modelled LWI correlate to measured LWI with $r=0.95$ at a RMSE of $8.3 \mathrm{~W} \mathrm{~m}^{-2}$ (Fig. 2).

$$
\begin{aligned}
F_{\mathrm{cl}} & =\frac{\mathrm{LWI}_{\text {all sky }}}{\mathrm{LWI}_{\text {clear sky }}}=-0.316 n_{\text {eff }}^{3}+0.2697 n_{\text {eff }}^{2} \\
& +0.39773 n_{\text {eff }}+0.97119
\end{aligned}
$$

To account for long-wave irradiance from surrounding terrain, LWI in the distributed MBM runs was finally computed as

$\mathrm{LWI}=s_{\mathrm{f}} \mathrm{LWI}_{\mathrm{sky}}+\left(1-s_{\mathrm{f}}\right) \varepsilon_{R} \sigma T_{R}^{4}$,

where $\mathrm{LWI}_{\text {sky }}$ is the long-wave irradiance from the sky (Eq. 3), $s_{\mathrm{f}}$ the sky view factor, $\varepsilon_{R}$ the terrain emissiv-

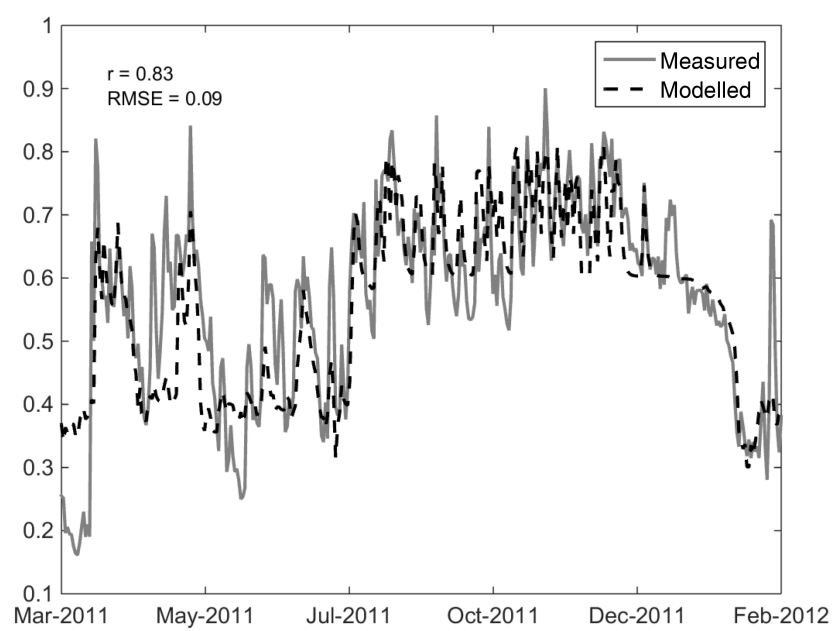

Figure 3. Daily mean values of measured and modelled $\alpha$ for the 358 day mass balance year 2 March 2011 until 22 February 2012.

ity (0.98), and $T_{R}$ the terrain temperature (absolute air temperature $+0.01 \mathrm{~K} \mathrm{~W}^{-1} \mathrm{~m}^{2} \mathrm{G}$ ), the latter being found less sensitive than $s_{\mathrm{f}}$ in steep topography of low latitudes (Sicart et al., 2006, 2011).

The parameterization of $\alpha$ (Fig. 3) is a function of snowfall frequency, time since the last snowfall, and snow depth (Oerlemans and Knap, 1998). The parameterization retains $\alpha$ of underlying snow, in case this layer becomes re-exposed after melting of new snow above (Gurgiser et al., 2013a; Mölg et al., 2012). The effects of snow ageing and snow depth on $\alpha$ are given by $e$-folding constants to compute values for $\alpha$ between constant fresh snow and firn albedos and variable ice albedo $\left(\alpha_{\text {ice }}\right)$, which is a function of the dew point temperature (DPT) $0.0056^{\circ} \mathrm{C}^{-1} \mathrm{DPT}+0.4179$ (Fig. 3). Hence, 
Table 2. Input parameters for the MBM showing the optimized value and the range permitted in the Monte Carlo simulation. Some parameters may differ from Nicholson et al. (2013), due to the use of a different model version employing parametrizations of sensitive model inputs such as albedo. Fresh snow density was obtained by in situ sampling, and similar values around $300 \mathrm{~kg} \mathrm{~m}^{-3}$ were previously reported for topical mountains in Bolivia and Tanzania (Mölg et al., 2008; Sicart et al., 2002).

\begin{tabular}{|c|c|c|c|c|}
\hline Parameter & Unit & Value & Range & Source \\
\hline $\begin{array}{l}\text { Penetration depth of daily } \\
\text { temperature cycle }\end{array}$ & $\mathrm{m}$ & 0.46 & $0.5 \pm 20 \%$ & Nicholson et al. (2013) \\
\hline z0 ice & $\mathrm{m}$ & $11 \times 10^{-3}$ & $\begin{array}{l}15 \times 10^{-3} \pm \\
5 \times 10^{-3}\end{array}$ & $\begin{array}{l}\text { Nicholson et al. (2013), } \\
\text { Winkler et al. (2009) }\end{array}$ \\
\hline z0 fresh snow & $\mathrm{m}$ & $0.4 \times 10^{-3}$ & $\begin{array}{l}0.5 \times 10^{-3} \pm \\
0.4 \times 10^{-3}\end{array}$ & Brock et al. (2006) \\
\hline z0 old snow & $\mathrm{m}$ & $6.6 \times 10^{-3}$ & $\begin{array}{l}4.5 \times 10^{-3} \pm \\
3.5 \times 10^{-3}\end{array}$ & Brock et al. (2006) \\
\hline Density of fresh snow & $\mathrm{kg} \mathrm{m}^{-3}$ & 315 & $370 \pm 60$ & $\begin{array}{l}\text { estimate from measurement, } \\
\text { Nicholson et al. (2013) }\end{array}$ \\
\hline $\begin{array}{l}\text { Bulk density of snowpack } \\
\text { at the beginning of run }\end{array}$ & $\mathrm{kg} \mathrm{m}^{-3}$ & 531 & $550 \pm 20 \%$ & $\begin{array}{l}\text { estimate from measurement, } \\
\text { Nicholson et al. (2013), } \\
\text { Hastenrath (1984) }\end{array}$ \\
\hline $\begin{array}{l}\text { Fraction of refreezing } \\
\text { meltwater forming } \\
\text { superimposed ice }\end{array}$ & $\%$ & 33 & $30 \pm 20 \%$ & Mölg et al. (2009b) \\
\hline $\begin{array}{l}\text { Fraction of SWI } \\
\text { penetrating ice/snow }\end{array}$ & $\%$ & $23 / 9$ & $\begin{array}{l}20 \pm 20 \% / \\
10 \pm 10 \%\end{array}$ & $\begin{array}{l}\text { Bintanja and van den Broeke } \\
\text { (1995), Mölg et al. (2008) }\end{array}$ \\
\hline $\begin{array}{l}\text { Extinction coefficient of } \\
\text { SWI in ice/snow }\end{array}$ & $\mathrm{m}^{-1}$ & $2.6 / 19.9$ & $\begin{array}{l}2.5 \pm 20 \% / \\
17.1 \pm 20 \%\end{array}$ & $\begin{array}{l}\text { Bintanja and van den Broeke } \\
\text { (1995), Mölg et al. (2008) }\end{array}$ \\
\hline $\begin{array}{l}\text { Bottom boundary } \\
\text { condition ice temperature }\end{array}$ & ${ }^{\circ} \mathrm{C}$ & -0.84 & $-1 \pm 1$ & $\begin{array}{l}\text { Thompson and Hastenrath } \\
\text { (1981), Nicholson et al. (2013) }\end{array}$ \\
\hline$\alpha$ firn & & 0.60 & $0.55 \pm 0.1$ & estimate from measurement \\
\hline$\alpha$ fresh snow & & 0.81 & $0.85 \pm 0.1$ & estimate from measurement \\
\hline Timescale & days & 1.3 & $3 \pm 2$ & Oerlemans and Knap (1998) \\
\hline Depth scale & $\mathrm{cm}$ & 4.1 & $5 \pm 4$ & Oerlemans and Knap (1998) \\
\hline
\end{tabular}

$\alpha_{\text {ice }}$ is adapted to tropical conditions, where ablation processes (melt or sublimation) strongly impact $\alpha_{\text {ice }}$ (Corripio and Purves, 2005; Mölg et al., 2008; Winkler et al., 2009).

\subsection{Model optimization and uncertainty estimation at the AWS}

Modelled mass balance sensitivity to individual parameters has been determined for this MBM for different climate settings in classical single-parameter variations (Mölg et al., 2009b) or multi-parameter variations through Monte Carlo approaches (Gurgiser et al., 2013a; Mölg et al., 2012). For LG, Nicholson et al. (2013) adopted the Monte Carlo approach to optimize the model parameters for the available periods of measured meteorological input at the point of the
AWS and evaluated the model performance against independent stake measurements. However, this does not provide an estimate of the model performance outside the period of optimization, which is an inadequate error assessment for sensitivity studies that involve forcing the model with perturbed meteorological conditions. In this study, model uncertainty at the AWS location was obtained by a combination of Monte Carlo optimization in conjunction with a $k$ fold cross-validation that provides a robust assessment of model performance outside the training period. The 773 days of meteorological input were divided into five periods for which MBM initialization (snow depth, TS, and an estimate of the number of days since the last snowfall event) was possible from independent field observations (Table 1). For each of the five $(k)$ periods, 1000 model realizations were 
performed, applying the Monte Carlo simulation with the same quasi-random parameter matrix, where each parameter spans a physically sound range based on measurements or previously published data (Table 2). Minimizing the combined RMSE between measured and modelled daily surface height change, daily means of TS, and $\alpha$ results in five optimal model parameter sets. To test their performance outside their optimization periods, these sets were cross-validated against the $k$ th period excluded from the optimization. Table 3 gives the obtained errors for surface height change, TS, and $\alpha$ for the whole range of 773 days and for the 2011/12 mass balance year represented by the last 358 days of the record, as this period is the focus of the subsequent sensitivity analysis. The modelled mass balance uncertainty for the mass balance year $2011 / 12$ is $\pm 154 \mathrm{~kg} \mathrm{~m}^{-2}$, derived from the RMSE in daily surface height change, together with a conservatively assumed density of $900 \mathrm{~kg} \mathrm{~m}^{-3}$. If the mass balance, modelled at the AWS location, is compared to the available independent measurements at the nearest ablation stake, which is $2 \mathrm{~m}$ away, the model uncertainty is $\pm 82 \mathrm{~kg} \mathrm{~m}^{-2}$, but the stake readings offer only two points in time for evaluation (the biannual ablation stake readings for 2011/12), and therefore the larger error is conservatively taken to be more representative of the model uncertainty.

\subsection{Distributing model input variables over the glacier surface}

After determining the MBM error at the point of the meteorological measurements, the MBM is applied in its distributed mode to the whole LG surface, represented in a digital elevation model (DEM) of $25 \mathrm{~m}$ grid point spacing. Vertical gradients are used to distribute precipitation and air temperature across the glacier surface and SWI and LWI are additionally modified by the sky view parameters for each DEM cell. Air pressure is adjusted according to the barometric height formula. In the absence of information, wind speed is assumed to be invariant over the small glacier area and by using relative humidity as input, the vapour pressure is scaled with the air temperature gradient. In the absence of other data on the gradients of input variables, the strategy employed here is to use existing records and theoretical considerations as far as possible and to optimize the gradients on the observed surface mass balance for 2011/12 as measured at the ablation stakes distributed across the glacier (Prinz et al., 2012). Accordingly, the gradient of precipitation from the terminus to the top of LG $\left(-0.00635 \% \mathrm{~m}^{-1}\right)$ was taken from a 9-year record (1981-1989) of concurrent precipitation measurements on Teleki Ranger Camp $(4200 \mathrm{~m}, \sim 2 \mathrm{~km}$ downslope of LG terminus) and Austrian Hut (4810 m, next to LG) (Hastenrath, 2005a). A negative precipitation gradient is a well-known feature on tropical mountains where the maximum precipitation occurs in the forest belt $(2000$ $3000 \mathrm{~m}$ ) and decreases towards the lowlands and the summits
Table 3. Model uncertainties expressed as root-mean-square error (RSME) and correlation coefficient $(r)$ for surface height change (sfc), daily mean surface temperature (TS), and albedo $(\alpha)$ at the location of the AWS.

\begin{tabular}{lcccccccc}
\hline & \multicolumn{3}{c}{ RSME } & & \multicolumn{3}{c}{$r$} \\
\cline { 2 - 4 } \cline { 6 - 8 } & sfc $(\mathrm{cm})$ & TS $\left({ }^{\circ} \mathrm{C}\right)$ & $\alpha$ & & sfc & TS & $\alpha$ \\
\hline All 773 days & 29.7 & 1.23 & 0.15 & & 0.81 & 0.72 & 0.54 \\
Last 358 days & 17.2 & 1.03 & 0.09 & & 0.78 & 0.78 & 0.83 \\
(i.e. mass balance & & & & & & \\
year 2011/12) & & & & & & \\
\hline
\end{tabular}

(e.g. Mölg, 2015; Røhr and Killingtveit, 2003; Thompson, 1966).

Vertical air temperature gradients in the surface layer immediately above the glacier vary over the diurnal cycle (Petersen and Pellicciotti, 2011). During daytime, turbulent mixing of the glacier boundary layer with the up-valley anabatic winds may erode the shallow katabatic layer of a small glacier (Ayala et al., 2015), and glacier boundary layer temperatures have been found to be higher than expected (Carturan et al., 2015). This effect is exacerbated by solar heating of the unglaciated terrain surrounding the glacier, which causes instability in the overlying boundary layer. In fact, advection of heat into the glacier boundary layer by both anabatic winds and the nearby unglaciated terrain have been reported for LG from early glacio-meteorological observations (Charnley, 1959; Davies et al., 1977; Platt, 1966). Accordingly, the model employs different vertical air temperature gradients for night-time and daytime (10:00-17:00 LT). During the night, the vertical air temperature gradient over the glacier was taken to be the moist adiabatic lapse rate of $-0.0065^{\circ} \mathrm{C} \mathrm{m}^{-1}$. As the available observed and modelled data do not allow for a quantified partitioning of potential dynamic processes that cause strong daytime gradients observed at the margins of glaciers (Ayala et al., 2015; Carturan et al., 2015; Petersen and Pellicciotti, 2011), the daytime gradient of $-0.015^{\circ} \mathrm{C} \mathrm{m}^{-1}$ was found through optimization using the spatially distributed stake mass balances of 2011/12. As the component of LWI that is parameterized for terrestrial irradiance from the surroundings is not constrained by measurements, the optimized daytime vertical air temperature gradient will also compensate for shortcomings in the LWI parameterization. LG spans only $220 \mathrm{~m}$ in altitude, so the mean nocturnal and diurnal air temperature differences from the top (measured) to the terminus of the glacier (from the optimized vertical air temperature gradient extrapolations) are 1.4 and $3.3^{\circ} \mathrm{C}$, respectively.

\subsection{Sampling synthetic climate scenarios}

As described by Nicholson et al. (2013) it is unlikely that a single climatic variable dominates the mass balance variability on LG. Thus, and because of the physical link between air temperature and vapour pressure (subsequently control- 
Table 4. Mean air temperature $(T)$, relative humidity $(\mathrm{RH})$, effective cloud cover fraction $\left(n_{\text {eff }}\right)$, wind speed $(v)$, and accumulation sum for different scenarios and the 2011/12 mass balance year, and for different seasons: annually (wet seasons/dry seasons). Mass balance modelled under each scenario for the 2010 glacier extent is denoted by $B\left( \pm 355 \mathrm{~kg} \mathrm{~m}^{-2}\right)$.

\begin{tabular}{|c|c|c|c|c|c|c|c|c|}
\hline \multirow[b]{2}{*}{$\begin{array}{l}\text { Variable } \\
\text { (unit) }\end{array}$} & \multicolumn{7}{|c|}{ Scenarios } & \multirow{2}{*}{$\begin{array}{l}\text { 2011/12 } \\
\text { REF }\end{array}$} \\
\hline & WW & $\mathrm{CD}$ & WET & DRY & AMPW & ATT & AMPC & \\
\hline$T\left({ }^{\circ} \mathrm{C}\right)$ & $\begin{array}{l}-0.11 \\
(-0.15 / \\
-0.06)\end{array}$ & $\begin{array}{l}-2.11 \\
(-2.11 / \\
-2.10)\end{array}$ & $\begin{array}{l}-1.05 \\
(-1.07 / \\
-1.03)\end{array}$ & $\begin{array}{l}-0.93 \\
(-0.92 / \\
-0.94)\end{array}$ & $\begin{array}{l}-1.13 \\
(-0.15 / \\
-2.10)\end{array}$ & $\begin{array}{l}-1.09 \\
(-2.11 / \\
-0.06)\end{array}$ & $\begin{array}{l}-1.59 \\
(-1.07 / \\
-2.10)\end{array}$ & $\begin{array}{l}-1.11 \\
(-0.96 / \\
-1.27)\end{array}$ \\
\hline RH (\%) & $\begin{array}{l}78 \\
(81 / 76)\end{array}$ & $\begin{array}{l}67 \\
(71 / 64)\end{array}$ & $\begin{array}{l}77 \\
(79 / 75)\end{array}$ & $\begin{array}{l}75 \\
(78 / 71)\end{array}$ & $\begin{array}{l}72 \\
(81 / 64)\end{array}$ & $\begin{array}{l}74 \\
(71 / 76)\end{array}$ & $\begin{array}{l}71 \\
(79 / 64)\end{array}$ & $\begin{array}{l}73 \\
(79 / 67)\end{array}$ \\
\hline$n_{\text {eff }}(\%)$ & $\begin{array}{l}28 \\
(29 / 27)\end{array}$ & $\begin{array}{l}23 \\
(26 / 21)\end{array}$ & $\begin{array}{l}28 \\
(28 / 27)\end{array}$ & $\begin{array}{l}26 \\
(28 / 24)\end{array}$ & $\begin{array}{l}25 \\
(29 / 21)\end{array}$ & $\begin{array}{l}26 \\
(26 / 27)\end{array}$ & $\begin{array}{l}25 \\
(28 / 21)\end{array}$ & $\begin{array}{l}26 \\
(27 / 26)\end{array}$ \\
\hline$v\left(\mathrm{~m} \mathrm{~s}^{-1}\right)$ & $\begin{array}{l}2.6 \\
(2.6 / 2.7)\end{array}$ & $\begin{array}{l}3.1 \\
(2.8 / 3.4)\end{array}$ & $\begin{array}{l}2.7 \\
(2.7 / 2.7)\end{array}$ & $\begin{array}{l}2.8 \\
(2.6 / 2.9)\end{array}$ & $\begin{array}{l}3.0 \\
(2.6 / 3.4)\end{array}$ & $\begin{array}{l}2.7 \\
(2.8 / 2.7)\end{array}$ & $\begin{array}{l}3.1 \\
(2.7 / 3.4)\end{array}$ & $\begin{array}{l}2.8 \\
(2.8 / 2.7)\end{array}$ \\
\hline $\begin{array}{l}\text { acc } \\
(\mathrm{cm})\end{array}$ & $\begin{array}{l}355 \\
(300 / 55)\end{array}$ & $\begin{array}{l}152 \\
(140 / 12)\end{array}$ & $\begin{array}{l}349 \\
(296 / 54)\end{array}$ & $\begin{array}{l}188 \\
(166 / 21)\end{array}$ & $\begin{array}{l}312 \\
(300 / 12)\end{array}$ & $\begin{array}{l}195 \\
(140 / 55)\end{array}$ & $\begin{array}{l}308 \\
(296 / 12)\end{array}$ & $\begin{array}{l}232 \\
(142 / 88)\end{array}$ \\
\hline $\begin{array}{l}B \\
\left(\mathrm{~kg} \mathrm{~m}^{-2}\right)\end{array}$ & $\begin{array}{l}-527 \\
(+580 /-1107)\end{array}$ & $\begin{array}{l}-578 \\
(+115 /-693)\end{array}$ & $\begin{array}{l}+447 \\
(+696 /-249)\end{array}$ & $\begin{array}{l}-1384 \\
(-186 /-1197)\end{array}$ & $\begin{array}{l}+66 \\
(+592 /-526)\end{array}$ & $\begin{array}{l}-1242 \\
(+112 /-1354)\end{array}$ & $\begin{array}{l}+260 \\
(+688 /-427)\end{array}$ & $\begin{array}{l}-966 \\
(-414 /-552)\end{array}$ \\
\hline
\end{tabular}

ling the turbulent heat fluxes and the parametrizations of the radiative fluxes), exploring mass balance sensitivity of single climatic variable perturbation was rejected in favour of coupled perturbations, reflecting the variability in the climate more comprehensively (Mölg et al., 2009b). To do this, alternative climate scenarios were constructed by resampling the AWS record on a diurnal basis in a manner similar to a simple weather generator (e.g. Hutchinson, 1987). Specifically, from the 773 days with meteorological data from LG AWS, 365 days (representing one arbitrary mass balance year from 1 March to 28 February) were repeatedly sampled at random until a synthetic annual climate was generated that met the following characteristics compared to the 2011/12 reference year (REF): $+1 \mathrm{~K}$ air temperature (warm and wet, $\mathrm{WW}$ ), $-1 \mathrm{~K}$ air temperature (cold and dry, CD), $+50 \%$ accumulation (WET), and $-20 \%$ accumulation (DRY). As the sampling was purely random, individual days can be selected more than once in a single synthetic year (i.e. sampling with replacement). It was not possible to obtain temperature perturbations in the absence of any accompanying precipitation perturbation, which highlights the fact that the prevailing temperature influences hygric conditions on the mountain. In contrast, precipitation scenarios can be sampled with little changes in air temperature. Whether this (de)coupling is an effect of the local atmosphere-mountain interactions or of the large-scale climate regime has not yet been explored. To maintain the actual hygric seasonality, the selected days were sorted according to their accumulation, with the wettest (driest) days randomly assigned to the wet (dry) seasons, minus 1 week to smooth the transitions between them. As there is insignificant seasonality in air temperature in this inner-tropical setting (Hastenrath, 1983), forced assigna- tion of the annual temperature variations was neglected. Although the period of available AWS data is short, it has been shown to be representative for the recent decades in terms of monthly ERA-Interim air temperature (1979-2012) and Tropical Rainfall Measuring Mission (TRMM) precipitation (1998-2012) time series (Fig. 3 in Nicholson et al., 2013). Thus, the synthetic scenarios can be considered representative of perturbations possible over the recent past, but it is not clear if they capture the full variable space of climatic conditions prior to 1980 . Nevertheless, these synthetic annual meteorological scenarios provide a useful and realistic basis to assess the sensitivity of the mass balance to a perturbation in its forcing climate within the context of the recent past.

High interannual variability in east African precipitation seasonality is characteristic for this region as droughts can occur and/or prolong into wet seasons and exchange with periods of above-normal precipitation, which has been observed in recent decades (e.g. Black et al., 2003; Nicholson, 2016). To cover the interannual variability, three further scenarios were constructed to explore the impact of potentially varying amplitudes of seasonal cycles: a warm amplification (AMPW) in which the wet seasons from WW and the dry seasons from $\mathrm{CD}$ are merged, a cold amplification (AMPC) in which the wet seasons from WET and the dry seasons from $\mathrm{CD}$ are merged, and an attenuated scenario (ATT) in which the wet seasons from CD are combined with the dry seasons from WW. Table 4 lists annual and seasonal statistics for all seven scenarios and the 2011/12 reference climate. This way a set of physically consistent and complex climate perturbations was obtained. Incoming radiative fluxes are parametrized from these resampled inputs as explained in Sect. 2.3. In the absence 
of any data, the $1 \mathrm{~K}$ perturbation for air temperature was chosen arbitrarily, but the perturbation in accumulation reflects measured precipitation variation at Austrian Hut between 1978 and 1996 (Hastenrath, 2005a). They show an annual minimum/mean/maximum of 480/850/1300 mm. Cumulative annual accumulation (i.e. snow depth in centimetres) from the scenarios converted with a fresh snow density of $315 \mathrm{~kg} \mathrm{~m}^{-3}$ (Table 2) yield annual precipitation sums between $480 \mathrm{~mm}(\mathrm{CD}), 731 \mathrm{~mm}$ (REF), and $1120 \mathrm{~mm}$ (WW), which are in the range of previously reported values.

\section{Results and discussion}

\subsection{The mass and energy balance for the year 2011/12}

Modelled annual mass balance at the 23 ablation stakes available for 2011/12 is significantly correlated to the measured mass balance with $r=0.86$ at an RSME of $320 \mathrm{~kg} \mathrm{~m}^{-2}$ (Fig. 4). Propagating the combined errors of the cross validation and comparison to the measured mass balance at all stakes, the modelled glacier mass balance for 2011/12 is $-911 \pm 355 \mathrm{~kg} \mathrm{~m}^{-2}$, which agrees well with the measured value ${ }^{1}$ of $-961 \mathrm{~kg} \mathrm{~m}^{-2}$. The model sensitivity of the mass balance to the vertical air temperature gradient is $-20 \mathrm{~kg} \mathrm{~m}^{-2}$ for each increase of $0.001{ }^{\circ} \mathrm{C} \mathrm{m}^{-1}$ (between -0.015 and $-0.0065^{\circ} \mathrm{C} \mathrm{m}^{-1}$ ) and $6 \mathrm{~kg} \mathrm{~m}^{-2}$ for each increase of the vertical precipitation gradient of $0.001 \% \mathrm{~m}^{-1}$ (between -0.005 and $-0.01 \% \mathrm{~m}^{-1}$ ).

Glacier-wide mean monthly energy and mass flux densities for 2011/12 are shown in Fig. 5. The governing role of the net short-wave flux on the energy and mass balance is clear. When $\alpha$ is high, due to abundant snow accumulation, the energy available for ablation is reduced, enabling conditions for net accumulation. In contrast, during the January/February dry season increased net radiation and turbulent fluxes cause high ablation rates. Both long-wave fluxes are almost constant throughout the year, as a potential lower LWI in colder and drier conditions is compensated by increased emission from surrounding terrain due to its enhanced solar heating, and TS reaches regularly $0{ }^{\circ} \mathrm{C}$. The seasonal cycle in 2011/12 is attenuated in the first half of the record and amplified in the latter, due to accumulation amounts below normal in the "long rains" and above normal in the "short rains", respectively (Nicholson et al., 2013).

The resultant mean annual glacier-wide mass and energy flux densities for the mass balance year 2011/12, which serves as a reference condition, are shown in Fig. 6. The net short-wave flux $\left(\mathrm{SW}_{\text {net }}\right)$ dominates the energy delivered to the glacier surface while the net long-wave flux $\left(\mathrm{LW}_{\text {net }}\right)$

\footnotetext{
${ }^{1}$ For the mass balance year 2011/12 Prinz et al. (2012) reported an annual mass balance of $-1030 \mathrm{~kg} \mathrm{~m}^{-2}$. This value changed to $-961 \mathrm{~kg} \mathrm{~m}^{-2}$ as the spatial interpolation of observed mass change from the ablation stakes to the glacier area was homogenized by using contours with constant equidistance.
}

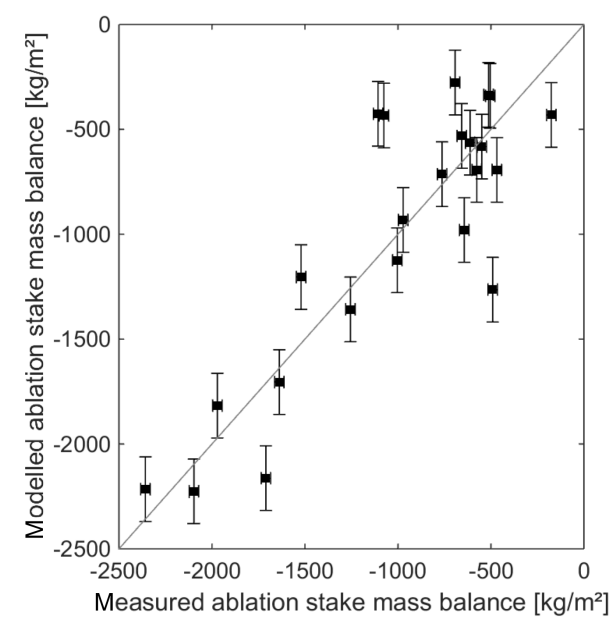

Figure 4. Model performance at the ablation stakes for the mass balance year 2011/12.

and $Q_{\mathrm{L}}$ are the largest energy sinks. $Q_{\mathrm{S}}$ is about $20 \%$ of $\mathrm{SW}_{\text {net }}$ and of equivalent magnitude to $Q_{\mathrm{M}}$, the resulting available energy for melt, that dominates ablation, in which the surface melt contributes $74 \%$ to the total ablation mass. Sublimation amounts to $15 \%$ of ablation and subsurface melt contributes $11 \%$. Subsurface melt and refreezing of meltwater are prominent features on LG and compare well with those described as important mass balance components in earlier studies (Charnley, 1959; Hastenrath, 1983; Platt, 1966). Snow accumulation is the dominant mass gain but, in 2011/12, not sufficient to compensate ablation.

\subsection{Glacier mass balance sensitivity to climate perturbations}

Figure 6 summarizes the energy and mass flux densities for the seven scenarios in comparison to the reference run. DRY and ATT produce the most negative annual mass balances due to reduced accumulation and enhanced energy surplus from the net radiative fluxes, which are in the order of REF. WW and CD yield similarly negative annual mass balances, but either compensate stronger mass losses through increased accumulation (WW) or shift energy available for ablation to "energy-expensive" $Q_{\mathrm{L}}(\mathrm{CD})$. In contrast, $Q_{\mathrm{L}}$ is small in WW and allows higher $Q_{\mathrm{M}}$ and depletes the positive effects of more accumulation. Consequently, the mass turnover is twice as high as in CD. Equilibrium or positive mass balances only occur if $\mathrm{SW}_{\text {net }}$ is reduced by $16-28 \%$ (13-23 $\mathrm{W} \mathrm{m}^{-2}$ ) (WET, AMPW, AMPC), a magnitude which can only be obtained by decreasing net short-wave radiation through higher albedo and enhanced cloudiness (Kruss and Hastenrath, 1987). Hence, accumulation must increase by $30 \%(100 \%)$ annually (wet season) from REF (Table 4). Dry season conditions can be either cold with little precipitation (WET - similar dry season climate as REF) or cold with dominantly clear sky conditions and thus very few ac- 

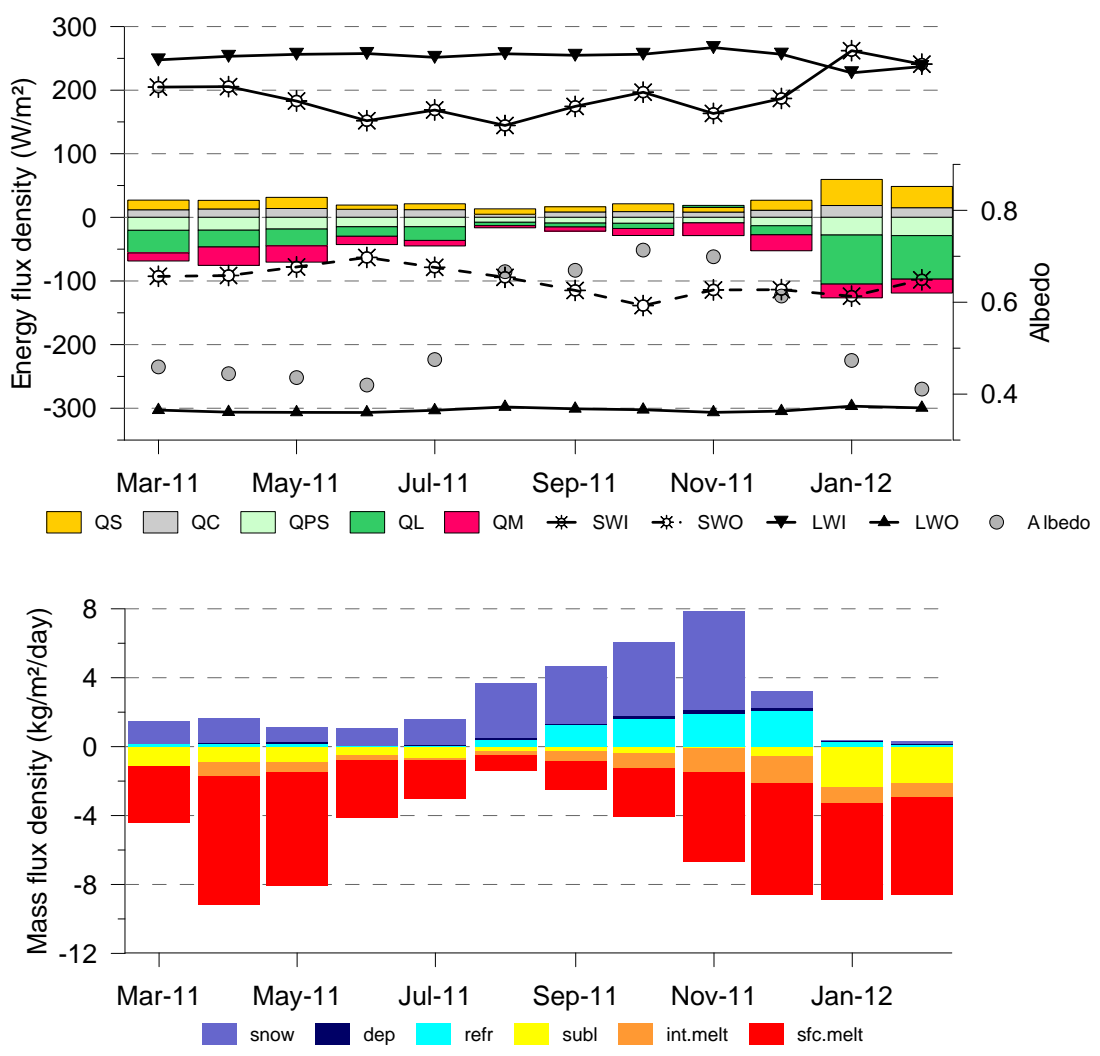

Figure 5. Glacier-wide mean monthly energy (upper panel) and mass flux densities (lower panel) for the mass balance year 2011/12 (REF): abbreviations as defined in Sect. 2.2 - the heat flux from precipitation is not shown due to its very low values; sfc.melt (surface melt), int.melt (internal melt in the subsurface), subl (sublimation), refr (refreezing), and dep (deposition).

cumulation events (AMPW, AMPC). For the latter it is crucial that albedo is high (from abundant wet season snowfall) to compensate for increased SWI from clear sky conditions. A summary of the climate variable space and resulting mass balances of the individual scenarios is given in Fig. 7.

All precipitation on Mt. Kenya is from convective atmospheric processes and during the available measurement period, all precipitation fell as graupel or snow in the vicinity of the AWS (Hastenrath, 1984; Nicholson et al., 2013). Although the MBM specifies that all precipitation is liquid above $4.5^{\circ} \mathrm{C}$ (which is the upper air temperature threshold at which solid precipitation was recorded at LG AWS), even in the warmest scenario (WW) only the lowest grid cell shows a slight decrease in accumulation due to $4 \%$ of the annual precipitation being rain instead of snow. Thus, due to the small elevation range of LG, contrary to other tropical mountains (Favier et al., 2004; Gurgiser et al., 2013a) there is no evidence that a phase change of precipitation impacts current LG retreat.

Could lower air temperatures alone bring the glacier to equilibrium, as suggested by Hastenrath (2010) from a simplified experiment which assumes both precipitation and radiative fluxes are constant, and both ice and air are at $0^{\circ} \mathrm{C}$ ? In the synthetic climate scenarios of this study, higher air tem- peratures persistently coincide with moist air and colder conditions with drier air (which is also confirmed by Chou and Neelin, 2004). No warm (cold) scenario without a significant increase (decrease) in moisture and consequent accumulation could be sampled from the available data. In contrast, it is possible to sample a wet (dry) scenario without changing the temperatures (Fig. 7); i.e. there is accumulation on cold days, but warm days without accumulation are very unlikely. This means that a change in the precipitation climatology of the mountain does not necessarily imply a change in air temperature, but a change in air temperature climatology always modifies the precipitation, a fact that was not captured in earlier sensitivity studies (Hastenrath and Kruss, 1992; Hastenrath, 2010; Kruss and Hastenrath, 1987, 1990; Kruss, 1983). As a consequence, lower air temperatures cannot exercise enough control on the energy balance to bring the glacier from its current imbalance to equilibrium, because a colder climate connotes reduced accumulation, as the $\mathrm{CD}$ and DRY scenarios confirm. Additionally, the colder scenarios show no reduced $Q_{\mathrm{S}}$ as the temperature difference between the glacier surface and the air above is maintained due to effective long-wave surface cooling and energy consumption by $Q_{\mathrm{L}}$, and higher wind speeds enhance both turbulent fluxes. Thus, the physically based modelling study presented 

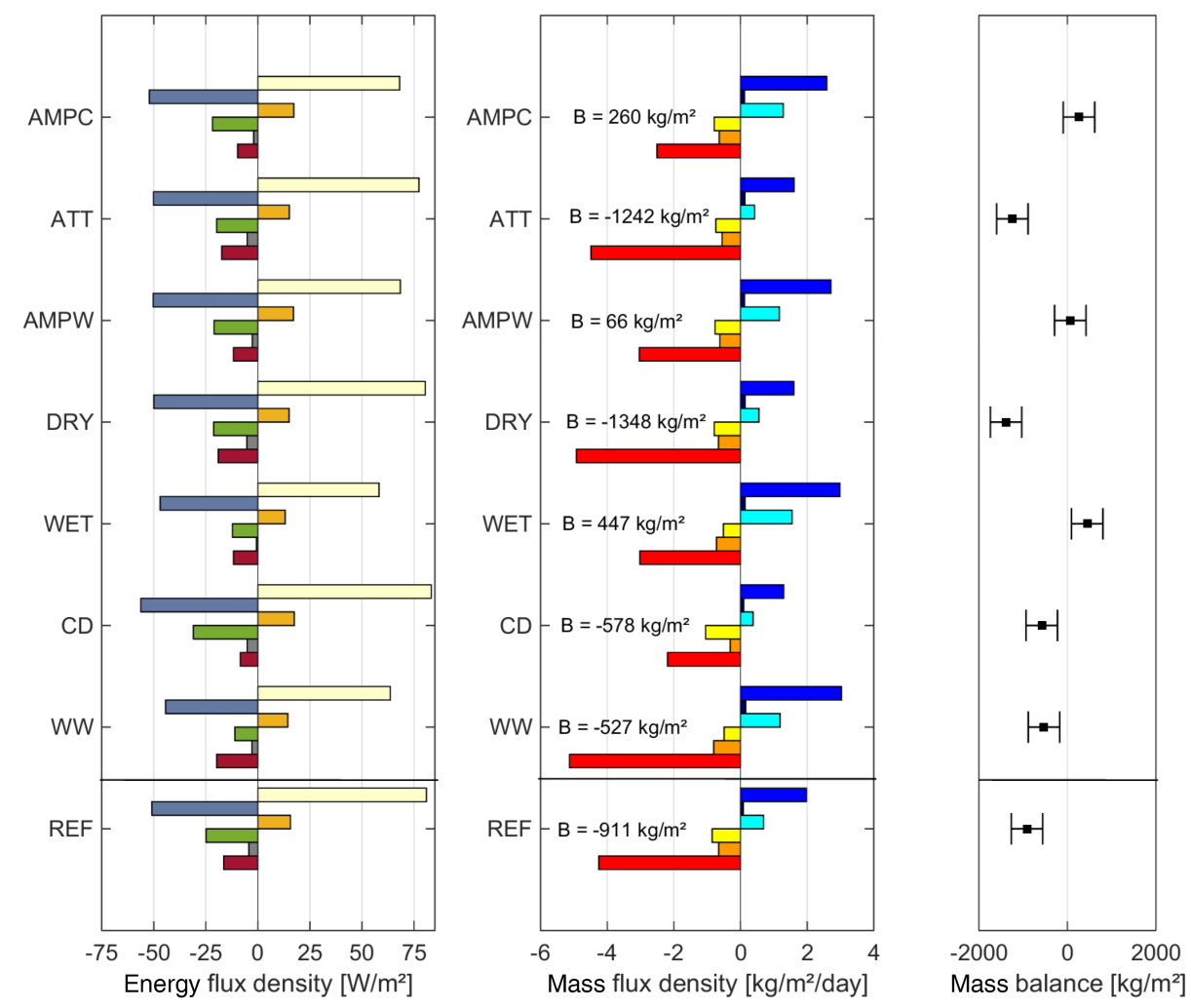

QM $\square$ QG $\square$ QL $\square$ QS $\square$ LWnet $\square$ sWnet

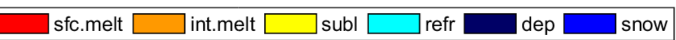

Figure 6. Glacier-wide mean energy (left panel) and mass flux densities (middle) for the eight different scenarios. The annual mass balances $(B)$ are shown in the middle panel and their error ranges in the right panel. Abbreviations as defined in Sect. 2.2 and Fig. 5, except $Q_{\mathrm{G}}$ (ground heat flux as the sum of $Q_{\mathrm{C}}$ and $Q_{\mathrm{PS}}$ ), $\mathrm{LW}_{\text {net }}$ (net long-wave radiative flux), and $\mathrm{SW}_{\text {net }}$ (net short-wave radiative flux).

here indicates that for climate scenarios that are within the limits of observations, only a change in the mountain's precipitation climatology to substantially more accumulation is able to sustain LG in its current extent.

\subsection{Modelling and interpreting L19 mass balance}

The mass balance model was applied to the LG in its L19 extent with the two most positive mass balance scenarios synthesized from the range of observed modern climate conditions (scenarios WET and AMPC) to see if these perturbed climates are sufficient to sustain the L19 glacier extent. The modelling produced negative mass balances in both cases of $-233 \mathrm{~kg} \mathrm{~m}^{-2}$ (WET) and $-338 \mathrm{~kg} \mathrm{~m}^{-2}$ (AMPC), respectively. Again, in these simulations, the impact of the strong air temperature gradient on the phase change of precipitation over the L19 extent is minor and confined to the lowest parts $(<4550 \mathrm{~m})$, where the maximum reduction of accumulation in favour of rain is $13 \%$ for the lowest grid point. Over the total glacier area, the fraction of rain is less than $1 \%$ for both WET and AMPC scenarios.

The negative mass balances for these scenarios, which are most favourable to glaciation, imply that even the extremes of the present-day climate are incapable of reproducing the L19 conditions. One interpretation of this finding is that the range of modern-day meteorological conditions in the summit region of Mt. Kenya no longer overlaps with the L19 range, and/or the covariance of meteorological conditions was substantially different in L19 than today.

\subsection{The impact of glacier extent on the proxy potential of Lewis Glacier}

Given that LG is now $83 \%$ smaller than its L19 extent, the relative importance of the glacier microclimate relative to the surrounding terrain is likely to have changed significantly between these two glacier geometries (Fig. 1). The limited aerial and vertical extent of the modern glacier favours the steep vertical air temperature gradient along the glacier surface, but on larger glaciers such as LG during its L19 extent, the air temperature gradient over the glacier surface is strongly modified by the katabatic wind field (Ayala et al., 2015; Greuell and Böhm, 1998; Shea and Moore, 2010); and the influence of long-wave emissions from surrounding terrain is drastically reduced as the glacier fills the cirque (Fig. 1).

Given the small area of LG in the modern day, it could be that the glacier is too small to form a substantial kata- 


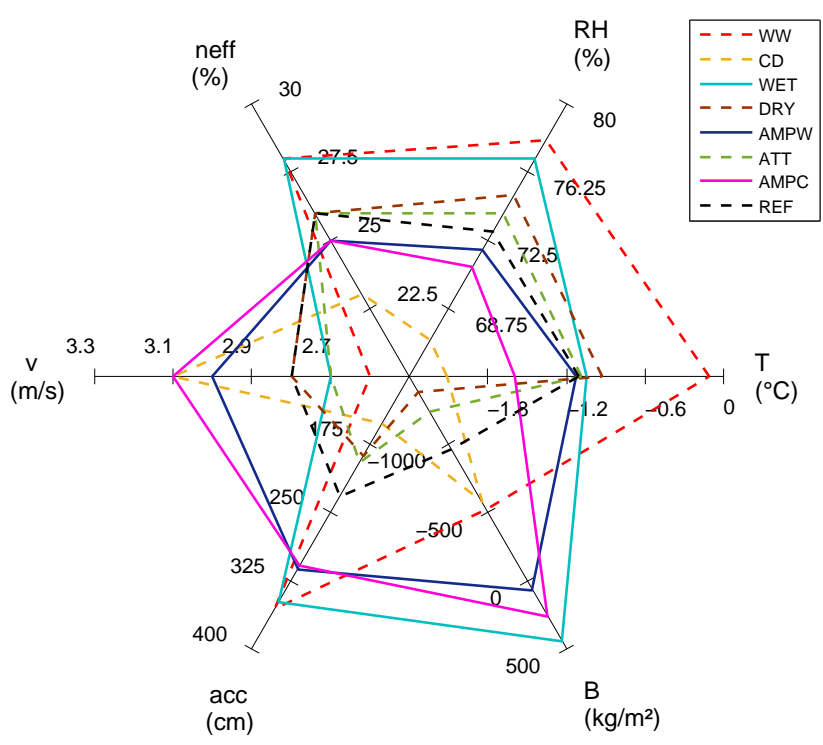

Figure 7. Spider plot showing the annual variable space of the individual climate scenarios. Solid (dashed) lines depict scenarios causing positive (negative) mass balances for the current extent of LG. Variable abbreviations are explained in Table 4. The REF year has similar characteristics as scenarios DRY and ATT, underlining the current accumulation deficit. Positive mass balances are a result of abundant accumulation and a complex interplay between decreased (increased) humidity and cloudiness, favouring long-wave surface cooling (reducing SWI).

batic layer and modify its own microclimate and is instead more strongly influenced by the surroundings with the offglacier boundary layer conditions dominating over much of the lower glacier. If this is the case, the air temperature distribution optimized for the modern-day LG extent cannot capture the dynamic processes that play a part in governing the air temperature distribution over the larger L19 glacier extent. Repeating the modelling for the L19 glacier extent using the moist adiabatic lapse rate for all hours of the day gives mass balances of 190 and $68 \mathrm{~kg} \mathrm{~m}^{-2}$ for WET and AMPC respectively, and quasi-zero mass balances $\left(17,-2 \mathrm{~kg} \mathrm{~m}^{-2}\right.$, for WET and AMPC respectively) can be achieved by using daytime vertical air temperature gradients of -0.010 and $-0.008^{\circ} \mathrm{C} \mathrm{m}^{-1}$, respectively. This supports the idea that a larger glacier can develop a deeper katabatic boundary layer that is more difficult to entrain through advection and turbulent mixing of warm air. Thus, reconstructions of former or future climates that are based on model optimizations for a modern-day glacier extent may not be applicable to substantially different glacier extents. This might have particular relevance for reconstructions based on very small glaciers such as LG, especially when glacier geometries have changed significantly. Ongoing retreat of remaining mountain glaciers suggests that scale effects such as this might also become increasingly important for palaeoclimate reconstructions from mountain glaciers worldwide in the future.

\section{Conclusions}

Distributed surface energy and mass balance modelling indicates that the energy and mass balance of present-day Lewis Glacier is most sensitive to atmospheric moisture (solid precipitation, cloudiness, and albedo). In the tropical atmosphere of Mount Kenya, air temperature changes are always coexistent with changes in atmospheric moisture; consequently, air temperature variation cannot be isolated as a single driver of glacier mass change. Although it has been proposed that a reduction in air temperature of $0.7^{\circ} \mathrm{C}$ would be sufficient to bring this small glacier to a zero mass balance state (Hastenrath, 2010), a colder climate scenario results in a less negative mass balance; but without additional accumulation, it is insufficient to achieve equilibrium.

Two scenarios suggest that higher accumulation $(+30$ to $+100 \%$ per year or wet season, respectively), higher relative humidity (4 to $8 \%$ units per year or dry season), a change of fractional cloud cover $(-5$ to $+1 \%$ units per dry season or year), and higher wind speed ( 0.3 to $0.6 \mathrm{~m} \mathrm{~s}^{-1}$ per year or dry season), which are all mutually linked, allow a zero mass balance for the present-day Lewis Glacier, without significant changes in the air temperature.

It is not possible to fully quantify the climatic conditions that could sustain LG at its maximum L19 extent, and there are two possible, and not necessarily mutually exclusive, interpretations of this finding.

i. Using the mass balance model as optimized for the modern-day glacier, driven by climate perturbations reflecting the observed variability in precipitation and air temperature over recent decades, results in negative mass balances. This would traditionally be interpreted to mean that L19 climate conditions at LG were distinctly different to the present day, and indeed that may well be the case.

ii. Alternatively or additionally, the modelling suggests that the L19 LG could be sustained if a favourable climate perturbation is applied in conjunction with a modification of the gradients used to extrapolate the AWS measurements over the glacier surface from those optimized for the very small modern-day LG. Such a modification might be justifiable in this case, where the modern-day glacier is so small that it is unlikely to generate significant microclimatological effects that would be expected for the larger L19 extent. In a general sense this finding indicates that extracting proxy climate conditions from a particular glacier geometry, using a modelling system optimized on a dramatically different geometry, may invalidate the approach, particularly if changes in boundary layer dynamics are substantial and not resolved in the model. This issue might warrant further investigation given that palaeoclimate reconstructions based on mountain glacier fluctuations inherently 
involve these scale contrasts; yet they are rarely considered in the tools used.

The modern-day sensitivity suggests that expanding LG to the L19 extent would require a change in the mountain's moisture regime to bring substantially more moisture and, consequently, more accumulation to the mountain. The same result was found for Kilimanjaro glaciers (Mölg et al., $2009 \mathrm{~b}$ ) and is supported by alternative climate proxies indicating abundant precipitation and high lake levels in the decades prior to 1880 (e.g. Konecky et al., 2014; Nicholson and Yin, 2001; Verschuren et al., 2000). Thus, it appears that, despite being close to the regional freezing level, the glaciers of Mt. Kenya do not offer a robust temperature proxy to complement the moisture proxy of the Kilimanjaro ice masses, and instead are also driven primarily by changes in atmospheric moisture, which confirms earlier conceptual considerations (Kaser et al., 2005). The large-scale climatological cause of present-day LG retreat, as well as of the shrinking ice on Kilimanjaro (Mölg et al., 2009b, 2013), is not completely understood yet and could be both natural variability and anthropogenic forcing. The first is identified in a recent study to cause the drying of east Africa, especially in the long rains (Schmocker et al., 2015; Yang et al., 2014b); while for the latter, a physical link from anthropogenic greenhouse gas and aerosol emissions to increased sea surface temperatures in the Indian Ocean and associated drying of east Africa has been established (Funk et al., 2008; Williams and Funk, 2011).

Acknowledgements. This study was granted by the Austrian Science Fund (FWF, P21288-N21). For logistical support, we are grateful to the Kenya National Council of Science and Technology, the Kenya Wildlife Service, Mt. Kenya National Park rangers, in particular Simon Gitau, Mt. Kenya Guides, and Porters Safari Club, our field assistants A. Fischer, S. Galos, M. Kaser, C. Lambrechts, M. Schultz, M. Stocker-Waldhuber, and P. Vettori, and UNEP who have all facilitated the data collection for this research. Thanks are also due to B. Marzeion and F. Maussion for fruitful discussions on the statistics, and to the reviewers, M. Rohrer and D. Samyn, for their valuable and constructive comments.

Edited by: A. Klein

\section{References}

Ayala, A., Pellicciotti, F., and Shea, J. M.: Modeling $2 \mathrm{~m}$ air temperatures over mountain glaciers: Exploring the influence of katabatic cooling and external warming, J. Geophys. Res.-Atmos., 120, 3139-3157, doi:10.1002/2015JD023137, 2015.

Bintanja, R. and van den Broeke, M. R.: The surface energy balance of Antarctic snow and blue ice, J. Appl. Meteorol., 34, 902-926, 1995.

Black, E., Slingo, J., and Sperber, K. R.: An Observational Study of the Relationship between Excessively Strong
Short Rains in Coastal East Africa and Indian Ocean SST, Mon. Weather Rev., 131, 74-94, doi:10.1175/15200493(2003)131<0074:AOSOTR>2.0.CO;2, 2003.

Brock, B. W., Willis, I. C., and Sharp, M. J.: Measurement and parameterization of aerodynamic roughness length variations at Haut Glacier d'Arolla, Switzerland, J. Glaciol., 52, 281-297, doi:10.3189/172756506781828746, 2006.

Brutsaert, W.: On a derivable formula for long-wave radiation from clear skies, Water Resour. Res., 11, 742-744, 1975.

Budyko, M. I.: Climate and Life, Academic Press, New York, London, 1974.

Carturan, L., Cazorzi, F., De Blasi, F., and Dalla Fontana, G.: Air temperature variability over three glaciers in the Ortles-Cevedale (Italian Alps): effects of glacier fragmentation, comparison of calculation methods, and impacts on mass balance modeling, The Cryosphere, 9, 1129-1146, doi:10.5194/tc-9-1129-2015, 2015.

Charnley, F. E.: Some observations on the glaciers of Mount Kenya, J. Glaciol., 3, 483-492, 1959.

Chou, C. and Neelin, J. D.: Mechanisms of global warming impacts on robustness of tropical precipitation asymmetry, J. Climate, 17, 2688-2701, doi:10.1175/15200442(2004)017<2688:MOGWIO>2.0.CO;2, 2004.

Chou, C., Neelin, J. D., Chen, C. A., and Tu, J. Y.: Evaluating the "rich-get-richer" mechanism in tropical precipitation change under global warming, J. Climate, 22, 1982-2005, doi:10.1175/2008JCLI2471.1, 2009.

Collier, E., Mölg, T., Maussion, F., Scherer, D., Mayer, C., and Bush, A. B. G.: High-resolution interactive modelling of the mountain glacier-atmosphere interface: An application over the Karakoram, The Cryosphere, 7, 779-795, doi:10.5194/tc-7-7792013, 2013.

Conway, J. P. and Cullen, N. J.: Cloud effects on the surface energy and mass balance of Brewster Glacier, New Zealand, The Cryosphere Discuss., 9, 975-1019, doi:10.5194/tcd-9-975-2015, 2015.

Corripio, J. G. and Purves, R. S.: Surface Energy Balance of High Altitude Glaciers in the Central Andes: the Effect of Snow Penitentes, in: Climate and Hydrology in Mountain Areas, edited by: de Jong, C., Collins, D., and Ranzi, R., John Wiley \& Sons, Ltd, Chichester., 15-27, 2005.

Cullen, N. J., Mölg, T., Kaser, G., Steffen, K., and Hardy, D. R.: Energy-balance model validation on the top of Kilimanjaro, Tanzania, using eddy covariance data, Ann. Glaciol., 46, 227-233, doi:10.3189/172756407782871224, 2007

Cullen, N. J., Sirguey, P., Mölg, T., Kaser, G., Winkler, M., and Fitzsimons, S. J.: A century of ice retreat on Kilimanjaro: the mapping reloaded, The Cryosphere, 7, 419-431, doi:10.5194/tc7-419-2013, 2013.

Cullen, N. J., Mölg, T., Conway, J., and Steffen, K.: Assessing the role of sublimation in the dry snow zone of the Greenland ice sheet in a warming world, J. Geophys. Res.-Atmos., 119, 65636577, doi:10.1002/2014JD021557, 2014.

Davies, T. D., Brimblecombe, P., and Vincent, C. E.: The daily cycle of weather on Mount Kenya, Weather, 32, 406-417, 1977.

Favier, V., Wagnon, P., Chazarin, J.-P., Maisincho, L., and Coudrain, A.: One-year measurements of surface heat budget on the ablation zone of Antizana Glacier 15, Ecuadorian Andes, J. Geophys. Res., 109, D18105, doi:10.1029/2003JD004359, 2004. 
Funk, C., Dettinger, M. D., Michaelsen, J. C., Verdin, J. P., Brown, M. E., Barlow, M., and Hoell, A.: Warming of the Indian Ocean threatens eastern and southern African food security but could be mitigated by agricultural development, P. Natl. Acad. Sci. USA, 105, 11081-11086, doi:10.1073/pnas.0708196105, 2008.

Greuell, W. and Böhm, R.: $2 \mathrm{~m}$ temperatures along melting midlatitude glaciers, and implications for the sensitivity of the mass balance to variations in temperature, J. Glaciol., 44, 9-20, 1998.

Gurgiser, W., Marzeion, B., Nicholson, L., Ortner, M., and Kaser, G.: Modeling energy and mass balance of Shallap Glacier, Peru, The Cryosphere, 7, 1787-1802, doi:10.5194/tc-7-17872013, 2013a.

Gurgiser, W., Mölg, T., Nicholson, L., and Kaser, G.: Mass-balance model parameter transferability on a tropical glacier, J. Glaciol., 59, 845-858, doi:10.3189/2013JoG12J226, 2013 b.

Hartmann, D. L., Klein Tank, A. M. G., Rusticucci, M., Alexander, L. V., Brönnimann, S., Charabi, Y., Dentener, F. J., Dlugokencky, E. J., Easterling, D. R., Kaplan, A., Soden, B. J., Thorne, P. W., Wild, M., and Zhai, P. M.: Observations: Atmosphere and Surface, in: Climate Change 2013: The Physical Science Basis, Contribution of Working Group I to the Fifth Assessment Report of the Intergovernmental Panel on Climate Change, edited by: Stocker, T. F., Qin, D., Plattner, G.-K., Tignor, M., Allen, S. K., Boschung, J., Nauels, A., Xia, Y., Bex, V., and Midgley, P. M., Cambridge University Press, Cambridge, UK and New York, NY, USA, 159-254, 2013.

Hastenrath, S.: Diurnal thermal forcing and hydrological response of Lewis Glacier, Mount Kenya, Arch. Meteorol. Geophys. Bioklimatol. A, 32, 361-373, 1983.

Hastenrath, S.: The Glaciers of Equatorial East Africa, D. Reidel Publishing Company, Dordrecht, Boston, Lancaster, 1984.

Hastenrath, S.: Glaciological Studies on Mount Kenya, University of Wisconsin-Madison, Madison, 2005a.

Hastenrath, S.: The glaciers of Mount Kenya 1899-2004, Erdkunde, 59, 120-125, doi:10.3112/erdkunde.2005.02.03, 2005 b.

Hastenrath, S.: Recession of Eqautorial Glaciers: A Photo Documentation, Sundog, Madison, 2008.

Hastenrath, S.: Climatic forcing of glacier thinning on the mountains of equatorial East Africa, Int. J. Climatol., 30, 146-152, doi:10.1002/joc.1866, 2010.

Hastenrath, S. and Kruss, P. D.: Greenhouse indicators in Kenya, Nature, 335, 503-504, 1992.

Hutchinson, M. F.: Methods of generation of weather sequences, in: Agricultural Environments: Characterization, Classification and Mapping, edited by: Bunting, A. H., CAB International, Wallingford, UK, 149-157, 1987.

Iqbal, M.: An Introduction to Solar Radiation, Academic Press Canada, Toronto, 1983.

Karl, T. R., Hassol, S. J., Miller, C. D., and Murray, W. L.: Temperature Trends in the Lower Atmosphere: Steps for Understanding and Reconciling Differences, General Books LLC, Washington, D.C., 2006.

Kaser, G., Georges, C., Juen, I., and Mölg, T.: Low-latitude glaciers: Unique global climate indicators and essential contributors to regional fresh water supply. A conceptual approach, in: Global Change and Mountain Regions: An Overview of Current Knowledge, edited by: Huber, U., Bugmann, H. K. M., and Reasoner, M. A., Kluwer, New York, 185-196, 2005.
Kaser, G., Mölg, T., Cullen, N. J., Hardy, D. R., and Winkler, M.: Is the decline of ice on Kilimanjaro unprecedented in the Holocene?, Holocene, 20, 1079-1091, doi:10.1177/0959683610369498, 2010.

Konecky, B., Russell, J., Huang, Y., Vuille, M., Cohen, L., and Street-Perrott, F. A.: Impact of monsoons, temperature, and $\mathrm{CO}_{2}$ on the rainfall and ecosystems of Mt. Kenya during the Common Era, Palaeogeogr. Palaeocl., 396, 17-25, doi:10.1016/j.palaeo.2013.12.037, 2014.

Kruss, P. D.: Climate change in east Africa: a numerical simulation from the 100 years of terminus record at Lewis Glacier, Mount Kenya, Kenya, Z. Gletscherkd. Glazialgeol., 19, 43-60, 1983.

Kruss, P. D. and Hastenrath, S.: The role of radiation geometry in the climate response of Mount Kenya's glaciers, part 1: Horizontal reference surfaces, Int. J. Climatol., 7, 493-505, doi:10.1002/joc.3370070505, 1987.

Kruss, P. D. and Hastenrath, S.: The role of radiation geometry in the climate response of Mount Kenya's glaciers, part 3: The latitude effect, Int. J. Climatol., 10, 321-328, doi:10.1002/joc.3370100309, 1990.

Lintner, B. R. and Neelin, J. D.: A prototype for convective margin shifts, Geophys. Res. Lett., 34, L05812, doi:10.1029/2006GL027305, 2007.

MacDonell, S., Kinnard, C., Mölg, T., Nicholson, L., and Abermann, J.: Meteorological drivers of ablation processes on a cold glacier in the semi-arid Andes of Chile, The Cryosphere, 7, 1513-1526, doi:10.5194/tc-7-1513-2013, 2013.

Meyers, T. P. and Dale, R. F.: Predicting daily insolation with hourly cloud height and coverage, J. Clim. Appl. Meteorol., 22, 537545, 1983.

Mölg, T.: Exploring the concept of maximum entropy production for the local atmosphere-glacier system, J. Adv. Model. Earth Syst., 7, 1-11, doi:10.1002/2014MS000404, 2015.

Mölg, T. and Hardy, D. R.: Ablation and associated energy balance of a horizontal glacier surface on Kilimanjaro, J. Geophys. Res., 109, D16104, doi:10.1029/2003JD004338, 2004.

Mölg, T., Renold, M., Vuille, M., Cullen, N. J., Stocker, T. F., and Kaser, G.: Indian Ocean zonal mode activity in a multicentury integration of a coupled AOGCM consistent with climate proxy data, Geophys. Res. Lett., 33, 1-5, doi:10.1029/2006GL026384, 2006.

Mölg, T., Cullen, N. J., Hardy, D. R., Kaser, G., and Klok, L.: Mass balance of a slope glacier on Kilimanjaro and its sensitivity to climate, Int. J. Climatol., 28, 881-892, doi:10.1002/joc.1589, 2008.

Mölg, T., Chiang, J. C. H., and Cullen, N. J.: Temporal precipitation variability versus altitude on a tropical high mountain: Observations and mesoscale atmospheric modelling, Q. J. Roy. Meteorol. Soc., 135, 1439-1455, doi:10.1002/qj.461, 2009a.

Mölg, T., Cullen, N. J., Hardy, D. R., Winkler, M., and Kaser, G.: Quantifying climate change in the tropical midtroposphere over East Africa from glacier shrinkage on Kilimanjaro, J. Climate, 22, 4162-4181, doi:10.1175/2009JCLI2954.1, 2009 b.

Mölg, T., Cullen, N. J., and Kaser, G.: Solar radiation, cloudiness and longwave radiation over low-latitude glaciers: implications for mass-balance modelling, J. Glaciol., 55, 292-302, 2009c.

Mölg, T., Maussion, F., Yang, W., and Scherer, D.: The footprint of Asian monsoon dynamics in the mass and energy balance of a Tibetan glacier, The Cryosphere, 6, 1445-1461, doi:10.5194/tc6-1445-2012, 2012. 
Mölg, T., Cullen, N. J., Hardy, D. R., Kaser, G., Nicholson, L., Prinz, R., and Winkler, M.: East African glacier loss and climate change: Corrections to the UNEP article "Africa without ice and snow”, Environ. Dev., 6, 1-6, doi:10.1016/j.envdev.2013.02.001, 2013.

Mölg, T., Maussion, F., and Scherer, D.: Mid-latitude westerlies as a driver of glacier variability in monsoonal High Asia, Nat. Clim. Change, 3, 68-73, doi:10.1038/nclimate2055, 2014.

Mutai, C. C. and Ward, M. N.: East African Rainfall and the Tropical Circulation/Convection on Intraseasonal to Interannual Timescales, J. Climate, 13, 3915-3939, doi:10.1175/15200442(2000)013<3915:EARATT>2.0.CO;2, 2000.

Nicholson, L. I., Prinz, R., Mölg, T., and Kaser, G.: Micrometeorological conditions and surface mass and energy fluxes on Lewis Glacier, Mt Kenya, in relation to other tropical glaciers, The Cryosphere, 7, 1205-1225, doi:10.5194/tc-7-1205-2013, 2013.

Nicholson, S. E.: A review of climate dynamics and climate variability in Eastern Africa, in: The Limnology, Climatology and Paleoclimatology of the East African Lakes, edited by: Johnson, T. C. and Odada, E., Gordon and Breach, Amsterdam, 25-56, 1996.

Nicholson, S. E.: An analysis of recent rainfall conditions in eastern Africa, Int. J. Climatol., 36, 526-532, doi:10.1002/joc.4358, 2016.

Nicholson, S. E. and Yin, X.: Rainfall conditions in Equatorial East Africa during the nineteenth Century as inferred from the record of Lake Victoria, Climatic Change, 48, 387-398, 2001.

Niemelä, S., Räisänen, P., and Savijärvi, H.: Comparison of surface radiative flux parameterisations. Part I: Longwave radiation, Atmos. Res., 58, 1-18, doi:10.1016/S0169-8095(01)000849, 2001.

Oerlemans, J. and Knap, W. H.: A 1 year record of global radiation and albedo in the ablation zone of Morteratschgletscher, Switzerland, J. Glaciol., 44, 231-238, 1998.

Patzelt, G., Schneider, E., and Moser, G.: Der Lewis-Gletscher, Mount Kenya: Begleitworte zur Gletscherkarte 1983, Z. Gletscherkd. Glazialgeol., 20, 177-195, 1984.

Pepin, N. C. and Lundquist, J. D.: Temperature trends at high elevations: Patterns across the globe, Geophys. Res. Lett., 35, 1-6, doi:10.1029/2008GL034026, 2008.

Petersen, L. and Pellicciotti, F.: Spatial and temporal variability of air temperature on a melting glacier: Atmospheric controls, extrapolation methods and their effect on melt modeling, Juncal Norte Glacier, Chile, J. Geophys. Res., 116, D23109, doi:10.1029/2011JD015842, 2011.

Platt, C. M.: Some observations on the climate of Lewis Glacier, Mount Kenya, during the rainy season, J. Glaciol., 6, 267-287, 1966.

Prinz, R., Fischer, A., Nicholson, L., and Kaser, G.: Seventysix years of mean mass balance rates derived from recent and re-evaluated ice volume measurements on tropical Lewis Glacier, Mount Kenya, Geophys. Res. Lett., 38, L20502, doi:10.1029/2011GL049208, 2011.

Prinz, R., Nicholson, L., and Kaser, G.: Variations of the Lewis Glacier, Mount Kenya, 2004-2012, Erdkunde, 66, 255-262, doi:10.3112/erdkunde.2012.03.05, 2012.

Røhr, P. C. and Killingtveit, A.: Rainfall distribution on the slopes of Mt Kilimanjaro, Hydrolog. Sci. J., 48, 65-77, doi:10.1623/hysj.48.1.65.43483, 2003.
Schmocker, J., Liniger, H. P., Ngeru, J. N., Brugnara, Y., Auchmann, R., and Brönnimann, S.: Trends in mean and extreme precipitation in the Mount Kenya region from observations and reanalyses, Int. J. Climatol., doi:10.1002/joc.4438, in press, 2015.

Schneider, E.: Begleitworte zur Karte des Mount Kenya in 1:10000, in: Khumbu Himal. Ergebnisse des Forschungsunternehmens Nepal Himalaya, edited by: Hellmich, W., Springer Verlag, Berlin, Göttongen, Heidelberg, 20-23, 1964.

Shea, J. M. and Moore, R. D.: Prediction of spatially distributed regional-scale fields of air temperature and vapor pressure over mountain glaciers, J. Geophys. Res., 115, 1-15, doi:10.1029/2010JD014351, 2010.

Sicart, J. E., Ribstein, P., Chazarin, J.-P., and Berthier, E.: Solid precipitation on a tropical glacier in Bolivia measured with an ultrasonic depth gauge, Water Resour. Res., 38, 1189, doi:10.1029/2002WR001402, 2002.

Sicart, J. E., Pomeroy, J. W., Essery, R., and Bewley, D.: Incoming longwave radiation to melting snow: observations, sensitivity, and estimation in northern environments, Hydrol. Process., 20, 3697-3708, doi:10.1002/hyp.6383, 2006.

Sicart, J. E., Hock, R., Ribstein, P., Litt, M., and Ramirez, E.: Analysis of seasonal variations in mass balance and meltwater discharge of the tropical Zongo Glacier by application of a distributed energy balance model, J. Geophys. Res., 116, D13105, doi:10.1029/2010JD015105, 2011.

Thompson, B. W.: The mean annual rainfall of Mount Kenya, Weather, 21, 48-49, 1966.

Thompson, L. G. and Hastenrath, S.: Climatic ice core studies at Lewis Glacier, Mount Kenya, Z. Gletscherkd. Glazialgeol., 17, 115-123, 1981.

Tierney, J. E., Smerdon, J. E., Anchukaitis, K. J., and Seager, R.: Multidecadal variability in East African hydroclimate controlled by the Indian Ocean, Nature, 493, 389-392, doi:10.1038/nature11785, 2013.

van den Broeke, M. R., Reijmer, C. H., van As, D., and Boot, W.: Daily cycle of the surface energy balance in Antarctica and the influence of clouds, Int. J. Climatol., 26, 1587-1605, doi:10.1002/joc.1323, 2006.

Verschuren, D., Laird, K. R., and Cumming, B. F.: Rainfall and drought in equatorial east Africa during the past 1,100 years, Nature, 403, 410-414, 2000.

Webster, P. J., Moore, A. M., Loschnigg, J. P., and Leben, R. R.: Coupled ocean-atmosphere dynamics in the Indian Ocean during 1997-98, Nature, 401, 356-360, doi:10.1038/43848, 1999.

Williams, A. P. and Funk, C.: A westward extension of the warm pool leads to a westward extension of the Walker circulation, drying eastern Africa, Clim. Dynam., 37, 2417-2435, doi:10.1007/s00382-010-0984-y, 2011.

Winkler, M., Juen, I., Mölg, T., Wagnon, P., Gómez, J., and Kaser, G.: Measured and modelled sublimation on the tropical Glaciar Artesonraju, Perú, The Cryosphere, 3, 21-30, doi:10.5194/tc-321-2009, 2009.

Winkler, M., Kaser, G., Cullen, N. J., Mölg, T., Hardy, D. R., and Pfeffer, W. T.: Land-based marginal ice cliffs: Focus on Kilimanjaro, Erdkunde, 64, 179-193, doi:10.3112/erdkunde.2010.02.05, 2010. 
Yang, W., Seager, R., Cane, M. A., and Lyon, B.: The Annual Cycle of the East African Precipitation, J. Climate, 28, 2385-2404, doi:10.1175/JCLI-D-14-00484.1, 2014a.
Yang, W., Seager, R., Cane, M. A., and Lyon, B.: The East African Long Rains in Observations and Models, J. Climate, 27, 71857202, doi:10.1175/JCLI-D-13-00447.1, 2014b. 